\title{
Henryka SĘDZIAK
}

\section{NAZWY MÓWIENIA W PRZEDWIOŚNIU STEFANA ŻEROMSKIEGO}

Mówienie jest procesem niezwykle złożonym, co znajduje wyraz w opisie ustnej komunikacji językowej. Ujawnia się tu bowiem nie tylko swoiste widzenie świata przez nadawcę wypowiedzi, ale także zastosowany sposób nazywania czynności mówienia. Wybór nominacji w znacznej mierze zależy od poziomu intelektualnego nadawcy. W moich pracach analizujących nazwy czynności mówienia $w$ tekstach gwarowych ${ }^{1}$ zwracałam uwage na ubóstwo środków nazywających działania słowne.

Przedmiotem niniejszego artykułu jest analiza nazw mówienia w utworze takiego mistrza słowa, jakim był Stefan Żeromski. Podstawę materiałową rozważań stanowią zdania nazywające mówienie w Przedwiośniu ${ }^{2}$. Świadomie unikam nazwy „czasowniki mówienia”, gdyż w utworze tym sytuacje mówienia wyrażają różne środki językowe. Można wśród nich wyodrębnić cztery zasadnicze grupy leksemów:

1. Czasowniki mówienia oznaczające 'komunikowanie słowami', np. mówić, powiedzieć, rzec, rozmawiać, szeptać i in.

2. Czasowniki zawierające komponent 'mówić’ ${ }^{3} \mathrm{w}$ strukturze semantycznej, ale nazywające inne czynności niż samo mówienie. Grupa leksemów tego typu jest szczególnie bogato reprezentowana w tekście Przedwiośnia. Występuje tu 100 czasowników, w tym 62 leksemy podstawowe i 38 czasowników pochodnych. Nazywają one różne działania słowne. Mówiący,

Semantyka i sktadnia czasowników mówienia w gwarze tomżyńskiej, Łomża 1992; Czasowniki mówienia $w$ gwarze tomżyńskiej, w: Polszczyzna Mazowsza i Podlasia. Kultura języka a regionalizmy, Warszawa 1993, s. 81-97; Zróżnicowanie znaczeniowe czasowników mówienia w gwarze tomżyńskiej w porównaniu z polszczyznq literackq, „Poradnik Językowy” 1992, s. 681688.

2 S. Żeromski, Utwory wybrane, t. 5, Przedwiośnie, Warszawa 1961.

3 Czasowniki z komponentem 'mówić' w strukturze semantycznej, „Prace Filologiczne” t. XXXIX, 1994, s. 335-349; Czasownikom tym poświęciłam pracę: Struktura semantyczna $i$ składniowa czasowników z komponentem 'mówić' (na materiale gwary tomżyńskiej), Warszawa 1995. 
wyzyskując funkcje języka, dąży do realizacji określonych celów. Jednym z komponentów semantycznych tych czasowników jest 'cel' realizowany poprzez mówienie. Czasownikom tym można przypisać funkcje:

2.1. funkcję deklaratywną, która realizują czasowniki: deklarować, obiecać, przyrzekać, przysięgać, a także grozić. Nadawca wypowiedzi podejmuje zobowiązania wobec przyszłego działania na korzyść bądź na niekorzyść adresata (np. grozić);

2.2. funkcję wyjaśniającą stosunek do innej, wcześniejszej informacji, np. klarować, perswadować, tłumaczyć, a także: kłamać, obgadywać, szkalować;

2.3. funkcję ekspresywno-impresywną pełnią czasowniki: chwalić, dziękować, błogosławić, życzyć, a także: bluźnić, drwić, gromić, klą́, tajać, napastować, podpuszczać, pomstować, sarkać, szydzić, uragać, wymyślać. Nadawca podejmuje działania słowne w celu wyrażenia uczuć wdzięczności bądź wywołania u adresata uczuć przykrych.

Czasowniki przedstawione w powyższych grupach nazywają działania nadawcy, które zakładają bierną postawę odbiorcy. Wśród czasowników nazywających różne działania realizowane za pomocą mówienia jest znaczna grupa leksemów oznaczających czynności słowne mające na celu oddziaływanie na odbiorcę, który powinien (musi) zareagować słowem lub odpowiednim zachowaniem. W tej grupie możemy wyodrębnić czasowniki pełniące:

a) funkcję performatywna, np. witać, żegnać. Czasowniki te nazywają działania wykonywane za pomocą wypowiedzi. Odbiorca powinien zachować się w sposób ustalony przez konwenans społeczny;

b) funkcję modalno-kauzatywną, np. agitować, błagać, dopominać się, kazać, prosić, pytać, radzić, wołać 'przyzywać, żadać, żebrać. Czasowniki te nazywają zachowania słowne nadawcy mające na celu skłonienie adresata do podjęcia określonych działań. W sytuacji opisanej przez te czasowniki istotna jest relacja osobowa: nadawca - odbiorca. Dominuje tu nierównorzędność uczestników procesu komunikacji, przy 
czym przewaga może być przypisana zarówno nadawcy, jak i odbiorcy komunikatu.

3. Czasowniki oznaczające różne czynności, a tylko kontekstowo zyskujące znaczenie 'mówić', np.

/1/ - Dobrześ to powiedzial, panie Czaruś! - westchnal ksiąz. (s. 118)

/2/ - Nastuś! Co ty po nocy wyśpiewujesz? - zaśmiala się panna Karolina. (s. 97)

/3/ - Doprawdy? Zasłabła? - zatroskal sie młody Baryka. (s. 102)

W tekście Przedwiośnia mamy w tej funkcji 47 czasowników, w tym 31 podstawowych i 16 pochodnych. W znaczeniu podstawowym, prymarnym nazywają one różne czynności. Często jednak ich wtórne znaczenia odnoszą się do procesu mówienia, np.

ciagnać 7. 'robić, mówić coś w dalszym ciagu',

dodać 2. 'powiedzieć coś jeszcze, dopowiedzieć',

odpalić 5. pot. 'odpowiedzieć ostro, stanowczo, zdecydowanie', szklić 2. pot. 'blagować, kłamać',

wyksztusić 2. 'wy powiedzieć coś $\mathrm{z}$ trudem, $\mathrm{z}$ wewnętrznymi oporami',

zagrzmieć 2. 'powiedzieć coś głośno, dobitnie, mocnym głosem'.

W omawianej tu funkcji wystapiły również czasowniki nazywające stany mentalne i emocjonalne, np. ciskać się, dziwić się, dowodzić, gorszyć się, irytować się, oburzać się, rozmyślać, wybuchnać, zaperzyć się. Wszystkie te czasowniki wprowadzają komunikat w postaci przytoczenia. Wg Emilii Kozarzewskiej ${ }^{5}$, czasowniki sporadycznie odnoszące się do procesu mowy wchodzą w związek składniowy wyłącznie z przytoczeniem, nie mogą tworzyć konstrukcji składniowych z rzeczownikiem oznaczającym tekst. Możliwość tworzenia takich konstrukcji jest cechą istotną, wyróżniającą verba dicendi.

4 Znaczenia czasowników podaję wg Stownika języka polskiego pod red. W. Doroszewskicgo, t. 1-11, Warszawa 1958-1969.

5 E. Kozarzewska, Czasowniki mówienia we wspótczesnym języku polskim. Studium semantyczno-skladniowe, Warszawa 1990, s. 13-14. 
4. Zwroty frazeologiczne oznaczające mówienie, np. wieść rozmowy 'rozmawiać', złożyć podzięke 'podziękować', wydać okrzyk 'krzyknąć', wydawać szepty 'szeptać', wszczynać kłótnie 'kłócić się, żqdać // zadawać pytanie 'pytać' (też: stawiać pytanie, rzucić pytanie, zwrócić się z pytaniem), napetnić wołaniem 'wołać'. W analizowanym tekście wystapiły 24 zwroty frazeologiczne, które należy uznać za warianty jednostek leksykalnych. Wszystkie zwroty mają podobną konstrukcję składniową: czasownik + rzeczownik nazywający mówienie $\mathrm{w}$ accusativie; czasem rzeczownik ma formę narzędnika.

W dalszych rozważaniach zajmę się tylko jednostkami należącymi do pierwszej grupy. Szczegółowa analiza struktury semantycznej, koniecznych uwarunkowań syntaktycznych oraz funkcji stylistycznej wszystkich leksemów nie jest możliwa w ramach artykułu. Zagadnieniu temu można by poświęcić odrębną monografię.

Podstawową funkcją czasowników mówienia jest komunikowanie myśli i przeżyć. Do grupy tej włączyłam czasowniki informować i komunikować, które Anna Pajdzińska ${ }^{6}$ określa jako hiperonimy czasowników mówienia. Leksemy te w przeciwieństwie do czasowników typu mówić, szeptać na poziomie leksykalnym nie przynoszą informacji o tym, w jaki sposób nadawca przekazał odbiorcy odpowiedni komunikat. Ze względu na ich pojedyncze wystapienia w omawianym tekście włączyłam je do grupy najbliższej im znaczeniowo.

W „Przedwiośniu” wystapiło 75 leksemów czasownikowych w znaczeniu 'komunikować słowami'. Są to czasowniki podstawowe i genetycznie $\mathrm{z}$ nimi związane czasowniki pochodne, $\mathrm{w}$ tym formacje prefiksalne $\mathrm{i}$ formacje $\mathrm{z}$ postfiksem się. Tabela 1 (na s. 115) przedstawia te czasowniki w układzie gniazdowym, podkreślającym pokrewieństwo językowe leksemów. Podałam tu tylko czasowniki, które znalazły potwierdzenie w tekście utworu. Niektóre leksemy nie wystąpiły tu $\mathrm{w}$ formie podstawowej. Poświadczone zostały tylko ich formy prefiksalne, np. przebqkiwać <- (bqkać), wyjakać <- (jakać), wypaplać <- (paplać). Czasowniki pochodne występujące $\mathrm{w}$ analizowanym tekście tworzone są za pomocą tylko 10-u prefiksów: $n a-, o-$, od-, po-, prze-,

6 A. Pajdzińska, Nazwy mówienia w języku polskim, w: Język a kultura, t. 2. Zagadnienia leksykalne i aksjologiczne pod red. J. Puzyniny i J. Bartminskiego, Wrocław 1991, s. 53-64. 
przy-, roz-, u-, wy-, za-. Wśród czasowników pochodnych są formy synchronicznie niemotywowane przez ich czasownikowe podstawy, np. odpowiadać, opowiadać, rozmawiać.

\section{Tabela 1. Czasowniki mówienia}

\begin{tabular}{|c|c|c|}
\hline Lp. & Czasownik & Lw. \\
\hline 1. & bajdurzyć & 1 \\
\hline 2. & bełkotać// bełkotnąć & 3 \\
\hline 3. & dysputować & 1 \\
\hline 4. & gadać & 22 \\
\hline 5. & pogadać & 1 \\
\hline 6. & przegadać & 2 \\
\hline 7. & rozgadać się & 1 \\
\hline 8. & wygadywać & 1 \\
\hline 9. & gawędzić & 1 \\
\hline 10. & ględzić & 1 \\
\hline 11. & glosić & 3 \\
\hline 12. & ogłosić & 2 \\
\hline 13. & gwarzyć & 1 \\
\hline 14. & informować & 1 \\
\hline 15. & kłócić się & 1 \\
\hline 16. & komunikować & 1 \\
\hline 17. & krzyczeć // krzyknąć & 19 \\
\hline 18. & pokrzykiwać & 1 \\
\hline 19. & przekrzykiwać & 1 \\
\hline 20. & wykrzykiwać // wykrzyknąć & 5 \\
\hline 21. & zakrzyknąć & 2 \\
\hline 22. & mamrotać & 3 \\
\hline 23. & mówić//mawiać & 150 \\
\hline 24. & namówić & 1 \\
\hline 25. & odmawiać // odmówić & 8 \\
\hline 26. & pomówić & 1 \\
\hline 27. & przemawiać//przemówić & 3 \\
\hline 28. & rozmawiać & 19 \\
\hline 29. & porozmawiać & 1 \\
\hline 30. & umówić & 2 \\
\hline 31. & umówić się & 1 \\
\hline 32. & wymawiać & 4 \\
\hline 33. & powiedzieć // powiadać & 48 \\
\hline 34. & odpowiadać // odpowiedzieć & 10 \\
\hline 35. & opowiadać // opowiedzieć & 16 \\
\hline 36. & naopowiadać & 1 \\
\hline 37. & rozpowiedzieć & 1 \\
\hline 38. & wypowiadać // wypowiedzieć & 2 \\
\hline
\end{tabular}

\begin{tabular}{|c|c|c|}
\hline Lp. & Czasownik & Lw. \\
\hline 39. & mruczeć // mnuknąć & 14 \\
\hline 40. & nadmienić & 1 \\
\hline 41. & napomknąć & 1 \\
\hline 42. & odzywać się & 4 \\
\hline 43. & ozwać się & 1 \\
\hline 44. & oponować & 1 \\
\hline 45. & oświadczać // oświadczyć & 7 \\
\hline 46. & pisnąć & 1 \\
\hline 47. & zapiszczeć & 1 \\
\hline 48. & pleść & 1 \\
\hline 49. & potakiwać & 1 \\
\hline 50. & powtarzać // powtórzyć & 9 \\
\hline 51. & prawić & 1 \\
\hline 52. & rozprawiać & 1 \\
\hline 53. & przebaliwać & 1 \\
\hline 54. & rzec & 34 \\
\hline 55. & odrzec & 1 \\
\hline 56. & przyrzec & 1 \\
\hline 57. & wyrzec & 2 \\
\hline 58. & spierać się & 1 \\
\hline 59. & spowiadać się & 1 \\
\hline 60. & szczebiotać & 1 \\
\hline 61. & szeptać // szepnąć & 27 \\
\hline 62. & poszeptać & 1 \\
\hline 63. & wyszeptać & 4 \\
\hline 64. & twierdzić & 3 \\
\hline 65. & potwierdzić & 1 \\
\hline 66. & wołać & 8 \\
\hline 67. & zawołać & 6 \\
\hline 68. & wrzeszczeć // wrzasnąć & 5 \\
\hline 69. & wywrzaskiwać & 1 \\
\hline 70. & zawrzeszczeć // zawrzasnać & 2 \\
\hline 71. & wtrącić & 6 \\
\hline 72. & wycedzić & 3 \\
\hline 73. & wyjąkać & 1 \\
\hline 74. & wypaplać & 1 \\
\hline \multirow[t]{2}{*}{75.} & wysyczeć & 1 \\
\hline & Razem & 498 \\
\hline
\end{tabular}


W analizowanych czasownikach pochodnych prefiksy pełnią trzy podstawowe funkcje:

a) zmieniają aspekt czasownika, np. szeptać -> wyszeptać, wolać -> zawolać:

/4/ - Mama czekata... - wyszeptat syn. (s. 47)

15/ - Patrz, jak mię ten wariat urzqdzit! - zawolat Hipolit, zeskakując z linijki na ziemie. (s. 106)

b) modyfikują znaczenie podstawy, np. porozmawiać, poszeptać:

16/ Przyjechała droga paniusia Kościeniecka, najmilsza sqsiadka porozmawiać o pikniku. (s. 162)

17/ Bezimienny przyjaciel poszeptat z ludźmi gwattownie i namiętnie. (s. 73)

Prefiks po- pełni tu funkcję okolicznika określającego treść podstawy pod względem czasu?

c) zmieniają znaczenie podstawy, wnosząc własną treść procesualną, np.namówić 'nakłonić kogoś do czegoś', wypaplać 'nie dochować tajemnicy, wygadać się'

18/ - Przecież toja go namówilem... I ty także!... (s. 156)

19/ - Zawiqżę ci tylko język na supel, ¿̇ebyś swoim miłym gajowcom czego nie wypaplat. (s. 216)

7 Aleksandra Krupianka, wychodząc z. koncepcji słowotwórczej Witolda Doroszewskiego, porównała stosunek między pniem a formantem ze stosunkiem składniowym w grupie orzeczenia zdania pojedynczego. Według autorki, tormant zastępuje okoliczniki określajace treść podstaw pod względem miejsca, czasu, sposobu. (Próba logiczno-syntaktycznej klasyfikacji polskich czasowników przedrostkowych, Z Polskich Studiów Slawistycznych. seria 3. Językoznawstwo, Warszawa 1968, s. 23-28). 
Czasownik namówić nazywa inną czynność realizowaną poprzez mówienie, należy więc do drugiej grupy leksemów z komponentem 'mówić'. Bywa też tak, że znaczenie czasownika podstawowego nie wiąże się $\mathbf{z}$ mówieniem, treść tę wnosi dopiero formant, np. cedzić -> wycedzić, syczeć -> wysyczec:

/10, - Szklane domy... - wycedzil przez zęby. (s. 159)

/11/ Po wykaszlaniu się wysyczat:

- Przyjdę po ciebie o dziesiątej rano. (s. 215)

wycedzić pot. 'powiedzieć coś powoli, z naciskiem',

wysyczeć 'wymówić coś ze złością, $\mathrm{z}$ pasją; często przez zaciśnięte zęby'.

Oba te czasowniki zawierają informacje o sposobie wytwarzania dźwięków.

Analiza 498 zdań z czasownikami mówienia uświadamia nam, że różne są struktury semantyczne omawianych leksemów, że odmiennie budują one perspektywę zdania. Opisowi semantycznemu poddane zostały tu głównie czasowniki podstawowe, gdyż przy klasyfikacji semantycznej czasowników prefiksalnych napotykamy trudności nie do pokonania. Zwrócił na to uwage Henryk Wróbel: „Wielość przedrostków i ich znaczeń w połączeniu ze znaczeniami leksykalnymi czasowników podstawowych daje ogromną liczbę kombinacji trudnych do rozgraniczenia i systematycznego opisania."

1. Jądrem semantycznym leksemów o znaczeniu 'komunikować słowami' jest czasownik mówić semantycznie najmniej złożony. Czasowniki mówić powiedzieć tworzące supletywną parę aspektową w analizowanym utworze występują najczęściej, tworzą bowiem 39,8 \% zdań z czasownikami mówienia. Czasownik mówić zdecydowanie dominuje w grupie tych leksemów. Wypowiedzenia z tym czasownikiem stanowią 30,2 \%, zaś z czasownikiem powiedzieć tylko 9,6\%. Czasowniki wielokrotne mawiać i powiadać należą tu do rzadkości. Z czasownikiem mawiać odnotowano tylko jedno zdanie:

8 H. Wróbel, O zasadach opisu stowotwórczego polskich czasowników prefiksalnych, „Studia Gramatyczne" 2, 1978, s. 105-119. 
/12/ Wiesz, jak to ten moskiewski ofik mawial w takich razach. (s. 110)

Czasownik powiadać, w słownikach polszczyzny współczesnej opatrzony kwalifikatorem przestarz, tworzy tu parę zdań, podkreślając wypowiedzi $\mathrm{w}$ stylu gawędziarskim:

/13/ ... kłaniat się panu dziedzicowi, co nie tylko z wojska wrócil, ale powiadali - wojnę wygral, samego Trockiego pobil na kwaśne jabłko. (s. 118)

/14/ Powiadal, iż ten to trupi zaduch przeszkadza, azeby moskiewskie powietrze można było wciagnać wolnymi i szczęśliwymi płucami. (s. 66)

Najbliższe znaczeniowo czasownikom mówić - powiedzieć są leksemy: odzywać się, rzec, gadać, prawić, oświadczać. Podstawową treścią semantyczna czasownika odzywać się jest mówienie. Emilia Kozarzewska ${ }^{9}$, autorka monografii o czasownikach mówienia, nie podaje leksemu odzywać się $\mathrm{w}$ indeksie czasowników o znaczeniu 'mówić'. Przestarzała forma ozwać się pojawiła się tu tylko $\mathrm{w}$ jednym zdaniu, nadając wypowiedzi pewną cechę archaiczności:

/15/ ... stuchat wyznania, wyraźniejszego, niżby być moglo, gdyby się ozwała ludzkimi stowy: (s. 41)

Czasownik rzec, którego znaczenie w Słowniku języka polskiego pod red. W. Doroszewskiego podane jest z kwalifikatorem ksiqż., nazywa sytuacje ustnej komunikacji w 34-ech zdaniach Przedwiośnia (6,8\% zdań z analizowanymi czasownikami). We wszystkich tych zdaniach ma on formę trzeciej osoby liczby pojedynczej czasu przeszłego i wprowadza komunikat $\mathrm{w}$ postaci mowy niezależnej. Oto przykłady:

/16/ - Zdaje mi się, że na nas ktoś wołat - rzekt Cezary. (s. 106)

/17/ - Byt taki staw u nas na Ukrainie..-rzekła panna Karolina. (s. 121)

9 E. Kozarzewska, op. cit., s. 224-225. 


\section{/18/ - Nie, Czaruś - rzekła - już z tobq nigdzie nie pójdę. (s. 238)}

Wydaje się, ze czasowniki gadać, prawić, oświadczać są nacechowane stylowo. Zastanawia stosunkowo częste użycie w tekście literackim czasownika gadać, który we współczesnej polszczyźnie ma wyraźnie charakter potoczny, często z odcieniem lekceważącym. W analizowanym tekście tworzy 22 zdania (4,4 \%). Przykłady zdań:

/19/ Krzyczeli poganiacze koni i głośno gadali pracownicy usiłujący przegadać huk maszyny. (s. 129)

\section{/20/ Gadała zaś niestworzone klituś-bajduś. (s. 24)}

/21/ Od razu widać było, ze będzie sowicie gadal, ze już glaska, ustawia w rzędach $i$ wypuszcza z klatek myśli połapane. (s. 218)

Analiza zdań z czasownikami gadać upoważnia do stwierdzenia, że relacjonuje on tu przede wszystkim wypowiedzi chłopów pracujących w Nawłoci, chłopów i komorników z Chłonka, warszawskich Żydów. Mamy tu do czynienia $z$ mową potoczną, $w$ której czasownik ten nie zachowuje nacechowania ujemnego (por. zdanie /19/). Inaczej się rzecz ma, gdy czasownik gadac referuje wypowiedzi przedstawicieli innych środowisk społecznych. Ujemną ocenę komunikatu zawierają zdania nazywające wypowiedzi komunistów na zebraniu (por. zdanie /21/), a także krytycznie oceniane przez Cezarego argumenty matki, której „klituś-bajduś” nie są pozbawione zdrowego rozsądku, a dowodzą zaślepienia syna. (zdanie /20/).

Czasownik prawić jest wyrazem przestarzałym, stosowanym dziś w określonym typie komunikatu, np. prawić moraly. W analizowanym tekście wystapił tylko w jednym zdaniu, w którym ma treść znaczeniową 'mówić, wyjaśniać':

122/ Prawila mu tedy, iż ten Tatar albo tamten Ormiaszka daje jej po starej znajomości parę garści żytniej maki. (s. 26)

Czasownik oświadczyć referuje komunikat o treści urzędowej, oficjalnej: 
123/ Maszynista oświadczyl sucho, że musi lokomotywie zrobić pewien remontik. (s. 61)

124/Wtedy robotnicy oświadczyli, że nie pozwolq zamknąć tej fabryki, (s. 241)

Analizując wypowiedzenia $\mathrm{z}$ omawianą grupą czasowników, dochodzimy do wniosku, że czasowniki te tworzą model zdania, w którym otwierają miejsca dla:

a) wykonawcy czynności (kto),

b) odbiorcy czynności, adresata (komu, do kogo),

c) komunikatu (co, o czym).

Nie wszystkie obligatoryjne uzupełnienia znajdują realizację $w$ strukturze zdania. Dotyczy to głównie nadawcy i odbiorcy komunikatu, których wykładniki leksykalne odnajdujemy często w kontekście. Przyjrzyjmy się strukturom składniowym tworzonym przez podstawowe czasowniki omawianej grupy:

/25/ Mówiq mi różne glupstwa a nawet świństwa. (s. 180)

/26/ Seweryn Baryka niewiele synowi mówil o swych praygodach na wojnach, (s. 48)

/27/ - Co za szkoda - mówiła piękna pani - ze nie byłam teraz $w$ domu.

(s. 136)

/28/ Mówil, ze pisze list otwarty do rodaków. (s. 203)

/29/ Zlote stowa powiedziateś. (s. 94)

/30/ A cóż powiesz o szkolach szklanych! (s. 57)

/31/- Powiem ci tylko jedno: tam w rowach nie byto pięknych kobiet. (s. 180) 
Jak wykazują powyższe zdania, uzupełnienia czasownika mogą mięć postać różnych wykładników. Wykonawca czynności, podmiot ma często wykładnik w postaci rzeczownika oznaczającego osobę (por. np. zdania /26/ i /27/). Podmiot może też być konotowany końcówką pierwszej lub drugiej osoby czasownika $^{10}$ (por. zdania /29/, /30/ i /31/). W zdaniach /25/, /28/ i /32/ mamy do czynienia z elipsą podmiotu, którego domyślamy się na podstawie kontekstu. Zdania /25/ i /32/ wskazują że wykonawcą czynności nie jest konkretna osoba, ale jakaś bliżej nieokreślona zbiorowość, co podkreśla liczba mnoga czasownika. Ten typ podmiotu domyślnego określany jest „osobowym uogólnionym""l.

Wykładnikami adresata wypowiedzi są najczęściej zaimki osobowe w dativie (por. zdania $/ 25 /, / 31 / \mathrm{i} / 32 /$ ), czasem rzeczownik również $\mathrm{w}$ tym przypadku (zdanie /26/).

W analizowanych zdaniach na ogół obecny jest wykładnik komunikatu. Ma on formę:

a) rzeczownika w bierniku, (co), por. zdania $/ 25 /, / 29 /, / 31 /$. W ostatnim zdaniu w tej funkcji wystapił liczebnik główny (jedno);

b) rzeczownika z przyimkiem w miejscowniku (o czym), zob. zdania /26/, $130 /$;

c) mowy niezależnej (zdania /27/,/31/);

d) mowy zależnej wprowadzanej najczęściej spójnikiem ̇̇e (zdania /28/, /32/).

Przy czasowniku mówić pozycja komunikatu nie jest wypełniana tylko w określonych sytuacjach, co wykażą przykłady zdań:

133/ Czaruśs stokroć lepiej mówit po rosyjsku niż po polsku. (s. 12)

'władał, posługiwał się danym językiem'

134/ [Seweryn] Mówil z przymknietymi oczyma, w odurzeniu od trujacego zaduchu wędrowców przemierzających równiny Rosji niezmierzonej. (s. 50)

10 S. Jodłowski, Podstawy polskiej składni, Warszawa 1976, s. 70.

$"$ A. Wierzbicka, Czy istnieja zdania bezpodmiotowe?, „Język Polski” XLVI, 1966, s. 177-196. 
135/ [Skalnicki] Mówit dobrotliwie, po ojcowsku i bardzo grzecznie. (s. 167)

Zdania /34/ i /35/ charakteryzują samą sytuację mówienia: sposób mówienia, okoliczności towarzyszące procesowi. Treść komunikatu odnajdujemy poza konstrukcją zdania.

Większość analizowanych w tej grupie czasowników realizuje schemat składniowy omówiony przy analizie czasowników mówić - powiedzieć. Wyjątek stanowi tu czasownik gadać, przy którym rzadziej jest wypełniona pozycja komunikatu; tylko $40,9 \%$ zdań z tym czasownikiem zawiera wykładniki tekstu. Mają one formę taka, jak w zdaniach konstytuowanych przez czasowniki mówić - powiedzieć. Pozostałe zdania z czasownikiem gadać informują o sposobie mówienia (por. podane wcześniej zdania /19/ - /21/).

2. Wśród czasowników mówienia podanych $w$ tabeli 1 (s. 115) można wyodrębnić leksemy, w których treść semantyczną jest wpisany element oceny komunikatu. Należą tu czasowniki: bajdurzyć, ględzić, paplać:

136/ ... lubit przypominać sobie różności ze swego życia i z życia ogótu, opowiadać - jednym stowem bajdurzyć. (s. 203)

137/Coś niezrozumiatego mamrotata i ględziła w kótko. (s. 166)

138/Co ksiqdz pleciesz! (s. 163)

Powyższe czasowniki zawierają negatywną ocenę komunikatu, wskazując jego nieprawdziwość i bezsensowność. Zdanie /36/ charakteryzuje sytuację mówienia, w której - podobnie jak w zdaniu /20/ - mamy bardzo subiektywną ocenę wypowiedzi przez odbiorcę. Młody i niedoświadczony Cezary nie potrafi właściwie ocenić argumentów zarówno matki jak i Gajowca. Czasownik ględzić informuje ponadto o sposobie mówienia, które jest rozwlekle i nudne.

Pewne treści związane $\mathrm{z}$ komunikatem zawierają $\mathrm{w}$ swej strukturze semantycznej czasowniki: glosić, twierdzić, spowiadać się. Treści te dotyczą ograniczeń związanych $\mathrm{z}$ realizacją typu komunikatu. Czasownik glosić łączy 
się najczęściej z takim wyrazem, w którego znaczeniu zawarta jest informacja o treści komunikatu:

139/ Ksiqdz mówil te słowa tonem mentorskim, jakby głosil jakq̨ś zasade moralna. (s. 145)

Przy czasowniku twierdzić może wystapić komunikat, o którego prawdziwości i słuszności przekonany jest nadawca:

/40/ Twierdzila, ze kto by chcial tworzyć ustrój komunistyczny, to powinien by podzielić na równe działy pusta ziemię, jakiś step, czy jakieś góry, i tam wspólnymi siłami orać, siać, budować, zać i zbierać. (s. 24)

W treści znaczeniowej czasownika spowiadać się zawarta jest informacja o specyficznym typie komunikatu (własne grzechy) i specyficznej sytuacji mówienia:

\section{/41/W Chyrowie się po tacinie spowiadat. (s. 157)}

Do czasowników referujących wypowiedzenia $\mathrm{z}$ określonym typem komunikatu zaliczyć można: nadmienić, napomknąc, wtrącić i przebqkiwać. Dwa pierwsze czasowniki są bardzo bliskie znaczeniowo, informują o komunikacie, jako o krótkiej wzmiance wygłoszonej marginesowo, mimochodem. Charakteryzują więc także sytuację, w której komunikat podano. Oto przykłady zdań z tymi czasownikami:

/42/ Trzeba nadmienić, iż Seweryn Baryka byt człowiekiem z gruntu i do dna uczciwym. (s. 9)

/43/ Nie powiedziat, oczywiście, wszystkiego, ale o tym $i$ owym napomknal. (s. 209)

Pewien element oceny komunikatu i sytuacji zawiera czasownik wtrącic:

144/ - Bo czasem - wtrqciła z pośpiechem pani Turzycka - Karusia dokładała cukru. (s. 168) 
Przebqkiwać to także 'mówić nieoficjalnie; napomykać':

/45/ Przebakiwal o powrocie do Warszawy i na medycynę, ale tylko dla pozoru... (s. 159)

Element oceny komunikatu zawierają antonimy potakiwać, oponować; wyrażają one stosunek do innej informacji: aprobują ją, bądź jej przeczą:

146/ Cezary stuchat, wzruszat się perypetiami procesu, potakiwat, przerazal się, nawet groził Żydom Kminkom. (s. 93)

/47/ Gdy byla z Cezarym sam na sam, próbowała oponować. (s. 24)

Stosunek do innej informacji wyraża też czasownik powtarzać. Powtarzanie służy utrwaleniu pewnych treści, zapamiętaniu, przekonaniu kogoś o czym:

148/ Gdy wracal do domu, powtarzal matce wszystko od a do z, wyjaśniał arkana co zawilsze. (s. 24)

Omawiane tu czasowniki tworzą struktury semantyczno-skladniowe zbliżone do modelu czasowników mówić - powiedzieć, z tą różnica, że przy czasownikach tej grupy, z wyjątkiem powtarzać nie jest wypełnione miejsce odbiorcy komunikatu. Zdania bez leksykalnego wykładnika adresata komunikują o nim implicite, ale nie dają na jego temat precyzyjnej informacji. Informacje te możemy uzyskać na podstawie kontekstu. Eksplicytny wykładnik adresata występuje tylko w zdaniach z czasownikiem powtarzać; w zdaniu /48/ ma on formę rzeczownika $\mathrm{w}$ dativie (komu) matce. W dwu innych zdaniach tworzonych przez ten czasownik miejsce adresata wypełnia zaimek sobie; zwrot: powtarzać sobie wskazuje na mowę wewnętrzna, będącą wyrazem przeżyć bohatera:

/49/ ... po sto tysięcy razy powtarzal sobie, ze nigdy tam juz noga jego nie postanie. (s. 173) 
3. Stosunkowo liczny zbiór stanowią tu leksemy charakteryzujące stronę artykulacyjno-foniczną mówienia ${ }^{12}$. Czasowniki te $w$ swej strukturze semantycznej zawierają element informujący o formie fonicznej wypowiedzi.

3.1. Wysokość i barwę głosu komunikują czasowniki piszczeć (tu tylko dk pisnqć), szczebiotać. Przykłady zdań:

150/ Skoro tylko Bulawnik trzasną drzwiami, az szyby zabrzęczały w całej kamienicy, Lulek pisnal:

-Ty! Stuchaj! (s. 214)

151/ [Lulek] wciqż coś złośliwego $i$ ośmieszajacego szczebiotat pokrywajac slowa histerycznym kaszlem. (s. 223)

3.2. O natężeniu głosu informują czasowniki oznaczające:

a) mówienie głośne: $k r z y c z e c ́$, wołać, wrzeszczeć

/52/ - Ukradli mi tę walizkę! - krzyknat Seweryn Baryka w uniesieniu. (s. 64)

/53/ - Ja ich nie biorę! - wołat głośno Białynia - Nie biorę! Nie biorę! (s. 70)

154/ - Leź do budy! - wrzasnal prawnik rozglqdając się na wszystkie strony. (s. 216)

b) mówienie ciche: mruczeć, szeptać

/55/ - Oto sq skutki wychowania w moskiewskim gimnazjum... - mruczat do otaczajacych ksiqdz Anastazy. (s. 156)

${ }^{12}$ Czasowniki te charakteryzował M. Mączyński w artykule $O$ czasownikach onomatopeicznych oznaczajacych mówienie, „Język Polski” LXIV. 1984, s. 99-109. J. Bartmiński analizując gwarowe nazwy zwiazane $\mathbf{z}$ wadami wymowy, przedstawił bogaty materiał leksykalny $\mathbf{w}$ swojej pracy Ludowe stownictwo logopedyczne, „Logopedia” 6, 1965, s. 66-85. Wiele czasowników tego typu omówiłam w książce o czasownikach mówienia w gwarze łomżyńskiej (op. cit., s. 112-136). 
/56/ Nie shyszqc, slyszała wyrazy, które do siebie w tańcu szeptali. (s. 152)

157/ - Pannie Karolinie przykro jest stuchać tej piosenki... - szepnat Cezary księdzu do ucha. (s. 115)

Czasownik szeptać stosunkowo częsty w analizowanym tekście, tworzy bowiem 27 zdań (5,4 \% zdań z czasownikami mówienia) oznacza nie tylko ciche mówienia, ale komunikuje, jak się wydaje, pewien nastrój intymności łączący rozmówców. Czasownik mruczeć oznacza mówienie ciche, ale i niewyraźne; łączy się zatem znaczeniowo z następną grupą leksemów.

3.3. Stopień poprawności realizacji fonicznej komunikują czasowniki: bełkotać, mamrotać, wyjakać (tylko w formie prefiksalnej).

158/ Lulek zjawit się obok Cezarego i, zaciśniętymi pięściami machając obok jego nosa, coś strasznie groźnego belkotat. (s. 223)

159/ Panowie w armiakach, magnaci w chlopskich rubaszkach, a mamrocza z cicha pomiędzy sobq po francusku. (s. 30)

/60/Coś wyjakal niezrozumiałego, co ledwie można było poją́:

-Terazjuż.. Terazjuż... w nogi! (s. 47)

Czasowniki charakteryzujące stronę artykulacyjno-foniczną mówienia często oprócz cech fizycznych tekstu określają także jego nadawcę. Zdania /50/, 151/ i /57/ z czasownikami piszczeć, szczebiotać i bełkotać wyraźnie ośmieszają postać komunisty Lulka. Czasowniki te tworzą struktury składniowe typowe dla czasowników o znaczeniu 'komunikować słowami'. Podobnie jak przy innych czasownikach zwykle wypełniona jest tu pozycja komunikatu; brak wykładnika tekstu w zdaniu /59/, w którym czasownik mamrotać charakteryzuje tylko sposób mówienia, nie relacjonuje konkretnej wypowiedzi. Częściej odnajdujemy w tych zdaniach wykładniki adresata wypowiedzi. Występują one eksplicytnie w zdaniach /55/, /56/, /57/ i /59/. Wykładniki przedstawione implicytnie sygnalizują różne środki językowe: 
a) zaimek osobowy ty, stanowiący zwrot do słuchacza (zdanie $/ 50 /$ ),

b) forma drugiej osoby trybu rozkazującego czasownika (zdania /50/ i/54/).

4. Wszystkie analizowane dotychczas czasowniki określały nierównorzędną postawę uczestników procesu mówienia: postawę aktywną nadawcy wypowiedzi i pasywną - odbiorcy komunikatu. Do czasowników mówienia należą również jednostki leksykalne oznaczające działania zbiorowe, w których czynnie uczestniczą co najmniej dwie osoby. Sytuacje komunikowania się ze sobą paru osób opisywane są w tekście Przedwiośnia przez następujące czasowniki: gawędzić, gwarzyć, dysputować, kłócić się, rozmawiać, spierać się, umawiać się. Są to czasowniki dyskursywne ${ }^{13}$, które oznaczają równorzędne relacje osobowe miedzy uczestnikami procesu mówienia. Uczestnicy dialogu czy polilogu pełnią podwójną rolę: nadawców i odbiorców wypowiedzi. W sytuacji dialogu (polilogu) każdy $\mathrm{z}$ uczestników bierze udział w tworzeniu tekstu. Współpraca miedzy uczestnikami komunikowania się przedstawia się różnie. Uczestnicy mogą reprezentować stanowiska jednakowe lub rozbieżne wobec tematu rozmowy.

4.1. W treści znaczeniowej czasowników dysputować, rozmawiać brak informacji o stanowiskach rozmówców wobec omawianej kwestii:

/61/ Pili we dwu z Baryka, raz wraz calujac się $i$ bez przerwy dysputujac. (s. 157)

162/ Pan Gajowiec chętnie z Cezarym rozmawiat. (s. 78)

163/ Ludzie rozmawiali szeptem i jakoś chytkiem, jak w kościele albo na pogrzebie. (s. 218)

4.2. Informacja o zgodności poglądów uczestników rozmowy wpisana jest w strukturę znaczeniową czasowników gawędzić, gwarzyć, umawiać się:

13 Tak nazwała czasowniki tego typu E. Kozarzewska (op. cit., s. 152-178). Czasownikami symetrycznymi nazywaja te leksemy J. Beller i Z. Saloni, autorzy artykułu $O$ opisie semantycznym haset czasownikowych, w: Semantyka i stownik pod red. A. Wierzbickiej, Wroclaw 1972, s. 230. 
164/.Jesśc możemy pospotu, gawędzić, urżnqcé się również, bo to ksiqdz lubisz... (s. 178)

165/ Jakże uwielbial cichq poufność rozmowy z niq o rzeczach niepowszednich i niezyciowych, kiedy gwarzyla z serca do serca o duszy swojej i o duszy przyjaciela. (s. 161)

166/ Umówiliśmy się, że gdy odjedzie, ja będę siedziała w oknie dopóty, dopóki latarnie jego wolanta będzie na polach widać. (s. 142)

O różnicy poglądów rozmówców informują czasowniki: kłócić się, spierać się:

/67/ [Żydzi] watęsali się $i$ zalewali ulice, brodzili, wchodzili $i$ wychodzili, gadali, klócili się nic wlaściwie nie robiąc. (s. 202)

168/Spierali się - jużtylko pomiędzy sobq - o to,jak też zachowywać się będa po wkroczeniu do Warszawy owi nie znani tu jeszcze bolszewicy. (s. 79)

W zdaniach z czasownikami dyskursywnymi czasownik konotuje co najmniej dwóch wykonawców czynności. W strukturze zdania relacja osobowa między uczestnikami rozmowy może być przedstawiona dwojako:

a) w formie podmiotu wyrażonego szeregiem wyrazów lub liczbą mnogą wykładnika podmiotu (por. zdania /63/i /67/, /68/).

b) w formie podmiotu z narzędnikiem towarzysza (zob. zdanie/62/).

W pierwszym wypadku uczestnicy rozmowy występują na tych samych prawach. Stosunek partnerski rozmówców uwydatnia liczba mnoga czasownika. Zdanie zawierające podmiot $\mathrm{z}$ narzędnikiem towarzysza sygnalizuje nierówny status uczestników procesu mówienia. Podkreśla to liczba pojedyncza orzeczenia. Wykładnik drugiego uczestnika rozmowy nie zawsze występuje w strukturze zdania, czasem odnajdujemy go w kontekście (zob. zdania /61/i / 65/). W zdaniu /65/ przy braku eksplicytnego wykładnika drugiego rozmówcy i liczbie pojedynczej wykładnika predykatu trudno orzec, czy mamy tu do czynienia ze „współtworzeniem” tekstu. 
Analiza nazw mówienia w „Przedwiośniu” wykazała duże bogactwo środków językowych występujących w funkcji nazw działań słownych. Są to nazwy zróżnicowane. Liczbowo ujmuje to tabela 2.

Tabela 2. Nazwy mówienia

\begin{tabular}{|l|l|c|c|c|c|}
\hline Lp. & \multicolumn{1}{|c|}{ Nazwy mówienia } & $\begin{array}{c}\text { Liczba } \\
\text { leksemów }\end{array}$ & $\%$ & $\begin{array}{c}\text { Liczba } \\
\text { wystapień }\end{array}$ & $\%$ \\
\hline 1. & $\begin{array}{l}\text { Czasowniki mówienia oznaczające } \\
\text { 'komunikowanie słowami' }\end{array}$ & 75 & 30,5 & 498 & 53,6 \\
\hline 2. & $\begin{array}{l}\text { Czasowniki zawierające kompo- } \\
\text { nent 'mówić' }\end{array}$ & 100 & 40,6 & 312 & 33,5 \\
\hline 3. & $\begin{array}{l}\text { Czasowniki oznaczajace różne } \\
\text { czynności, a tylko kontekstowo } \\
\text { zyskujące znaczenie 'mówić' }\end{array}$ & 47 & 19,1 & 91 & 9,8 \\
\hline 4. & Zwroty frazeologiczne & 24 & 9,8 & 29 & 3,1 \\
\hline & Razem: & 246 & 100,0 & 930 & 100,0 \\
\hline
\end{tabular}

246 jednostek leksykalnych wykorzystał pisarz do relacjonowania wypowiedzi. Tworzą one 930 zdań. W 53,6 \% omawianych zdań wypowiedzi referowane są przez czasowniki mówienia. Najczęściej występu ją tu czasowniki: mówić, powiedzieć, rzec, szeptać, gadać, rozmawiać (por. tabela 1). Inne leksemy o znaczeniu 'komunikować ustnie' rzadko relacjonują wypowiedzi; aż 41 czasowników to pojedyncze użycia w tekście Przedwiośnia.

Podobnie przedstawia się sytuacja w grupie leksemów z komponentem 'mówić'. 100 czasowników tworzy tylko 312 zdań. Dominują czasowniki: prosić, pytać, blagać, kazać, tłumaczyć; 56 czasowników to pojedyncze wystapienia w tekście omawianego utworu. Jeszcze mniejszą frekwencją odznaczają się czasowniki tylko kontekstowo oznaczające mówienie; 47 leksemów wystąpiło tylko w 91 zdaniach.

Przedstawiony wyżej materiał językowy upoważnia do stwierdzenia, że $\mathrm{z}$ wielkim wyczuciem językowym stosował pisarz różne środki w nazywaniu sytuacji mówienia. Oprócz leksemów, których podstawową funkcją jest 'komunikowanie słowami' wykorzystał czasowniki nazywające różne czynności realizowane za pomocą mówienia, a także te leksemy, które tylko wtórnym swym znaczeniu wiążą się z mówieniem. Wprowadził też zwroty frazeologiczne 
jako warianty leksemów mówienia. Wykorzystując bogactwo środków językowych, zobrazował różnorodne relacje zachodzące miedzy podstawowymi komponentami wypowiedzi: nadawca, odbiorcą i tekstem. W sposób mistrzowski wyzyskał wszystkie odcienie znaczeniowe omawianych leksemów. Zawarta w strukturze semantycznej jednostek leksykalnych negatywna ocena nadawców i ich komunikatów posłużyła pisarzowi do ośmieszenia jego przeciwników ideowych.

Był Żeromski - jak słusznie stwierdzają znawcy jego twórczości „wielkim pomnożycielem polszczyzny - rozszerzał ją o nowe pokłady stylistyczne, o nowe sposoby przekazywania słowem zarówno prawdy wewnętrznej człowieka, jak i urody, i potworności widzialnego świata."14 Twórczość jego cechuje „,bogactwo słownika, fenomenalna wydolność językowa i umiejętność znajdywania wyrazów w danym miejscu potrzebnych, nieodwołalnie trafnych."15

${ }_{14}$ S. Żeromski, Utwory wybrane, t. 1. Wstęp H. Markiewicz, Warszawa 1961, s. 22.

15 A. Hutnikiewicz, Stefan Żeromski, Warszawa 1963, s. 68. 